\title{
ČLÁNKY
}

\section{Minimální požadavky na odůvodnění správního rozhodnutí ve středoevropském kontextu}

\section{Minimum Requirements for the Reasoning of Administrative Decisions in the Context of Central Europe}

\author{
Radislav Bražina*
}

\begin{abstract}
Abstrakt
Tématem článku je problematika minimálních standardio odivvodnèni správnich rozhodnutí ve strédoevropském kontextu, tj. ve svètle právni úpravy Céské republiky, Nèmecka, Rakouska a Polska s prïblédnutím k dokumentim Rady Evropy a judikature ESLP. Oduivodnèni získává své misto v oblasti záruk zákonnosti ve veréjné správy a v systému ochrany práv adresátu verejné správy, pričemž tento článek analyzuje společný sdílený minimálni nárokù kladených na odiuvodnèní za pomocí studia odborné literatury, analýay

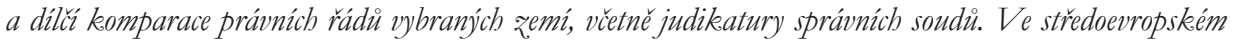
prostredí je sjednocujicim prvkem minimálních požadavkè na odìvodnèni (s mirnými odchylkami) povinnost správníbo orgánu uvést zásadni (podstatné) divvody vedouci správni orgán ke vydáni daného rozhodnutí ve spojeni s hodnocením podkladi rǐzeni a dikkazủ. Této otáz̨ce je vènována blavni cást článku. Autor se zabývá i možnostmi vydáni roz̧hodnuti bez odivodnèni. Tyto výjimky analyzuje a zaměruje se zejména na problematiku jejich souladnosti se zásadou rádnébo odivvodnèní jako tǒto jedné z obecných právních zásad.
\end{abstract}

Klíčová slova

zásada rádného odivvodnèní; odîvodnèní; úplnost odiovodnèni; minimální požadavky na odìvodnèní.

\section{Abstract}

The author in article deals with the minimum standards of reasoning of administrative decisions in the Central European context, ie. in the light of the legislation of the Czech Republic, Germany, Austria and Poland with regard to the documents of the Council of Europe and the case law of the ECHR. Reasoning guarantees legality in public administration and is important part of the system of protection of public individual rights, and this paper analyzes common shared minimal demands on reasoning using a study of the literature, analysis and partial comparison of legal systems in selected countries, including the case law of the administrative courts. In Central Europe, the unifying element of the minimum requirements for reasoning (with slight variations) is the duty administrative authority to bring essential (substantial) reasons why the administrative authority take the decision in conjunction with the evaluation procedure documents and evidence. This issue is the main part of the article. The author also deals with the possibilities of issuing decisions without reasoning. These exceptions are analyzed mainly on the issues of the compliance with principle of proper reasoning as one of the general principles of law.

\footnotetext{
* Mgr. Radislav Bražina, Katedra správní vědy a správního práva, Právnická fakulta Masarykovy univerzity, Brno / Department of Administrative Studies and Administrative Law, Faculty of Law, Masaryk University, Brno, Czech Republic / E-mail: radislav.brazina@mail.muni.cz
} 


\section{Keywords}

Principle of Proper Reasoning; Reasoning; Completeness of reasoning; Minimal Standards of Reasoning.

\section{1 Úvod}

V rámci evropského správního prostoru má povinnost správních orgánů odůvodňovat rozhodnutí dlouholetou tradici. Již v roce 1925 československý nejvyšší správní soud zdůrazňoval povinnost odůvodnit správní rozhodnutí, a to zejména v situaci, kdy správní rozhodnutí zasahuje do subjektivních práv adresátů. ${ }^{1}$ Rozsah této povinnosti do dnešní doby prošel určitým vývojem. Cílem tohoto článku je analyzovat základní rozsah povinnosti odůvodnit správní rozhodnutí na př́kladu České republiky společně s Německem, Rakouskem a Polskem, a to pomocí studia judikatury správních soudů a ESLP, dále odborné literatury a základní komparace právních předpisů. Jelikož již při letmém pohledu do jednotlivých právních řádů vybraných států zjistíme, že právní rády všech zmíněných států obsahují povinnost správních orgánů odůvodnit svá rozhodnutí, je záměrem autora zjistit, zda uvedené státy sdílí společný minimální standard a rovněž uvést základní komentár k zahraniční právní úpravě. Autor se dále zaměří na výjimky z povinnosti odůvodnit správní rozhodnutí a jejich soulad se zásadou řádného odůvodnění. Pohled do zahraničních právních řádů může být podle názoru autora velmi zajímavý zejména $z$ toho důvodu, že vývoj právních řádů nebyl $\mathrm{v}$ uvedených státech zcela shodný. Přestože uvedená povinnost prošla ve zmíněných státech rozdílným vývojem, autor se domnívá, že vybraný vzorek států sdílí společný minimální standard vyhovující judikatuře ESLP. Kromě již zmíněné judikatury ESLP na členské státy Rady Evropy působí pozitivně i tzv. soft-law. Neméně významný vliv má i judikatura správních soudů a právní teorie. Na úvod je pak vhodné zmínit, že jak judikatura ESLP, tak teorie považuje právo na odůvodnění za součást práva na spravedlivý proces. ${ }^{2}$ Autor tohoto př́spěvku se domnívá, že povinnost odůvodnit správní rozhodnutí je již natolik vžitá, že ji lze považovat za obecnou právní zásadu. Tento názor potvrzuje česká i zahraniční doktrína, na níž bude odkázáno níže.

\section{Rada Evropy ${ }^{3}$}

Rozsah povinnosti odůvodnit rozhodnutí správních orgánu na evropské úrovni utváří soft-law Rady Evropy a zejména pak judikatura ESLP. Mezi významné dokumenty vě-

1 Boh. A 5207/25 (nález č. 20782/24) In: ONDRUŠ, Radek. Vybraná rozhodnutí Nejyyšš̌ibo sprámníbo soudu ve věcech administrativnich 1918-1948 a jejich využití v současné aplikačni praxi. Praha: Linde, 2001, s. 179.

2 MOLEK, Pavel. Právo na spravedlivý proces. 1. vyd. Praha: Wolters Kluwer Česká republika, 2012, s. 207.

3 Autor článku se přiklání k názoru V. Sládečka, který uvádí, že nároky plynoucí z Evropské úmluvy o ochraně lidských práv a základních svobod se ve správním řízení aplikují přiměřeně (viz SLÁDEČEK, Vladimír. Obecné správni právo. 3., aktualiz. a upr. vyd. Praha: Wolters Kluwer Česká republika, 2013, s. 440). Otázku, kdy se EÚLP ve správním řízení aplikuje a kdy nikoliv, nechává autor nezodpovězenou, nebot' kompletní odpověd' by zcela přesáhla rozsah tohoto článku. 
nující se povinnosti odůvodňovat rozhodnutí správních orgánů patří zejména Rezoluce Výboru ministrů Rady Evropy (77)31, ${ }^{4}$ podle které má správní orgán povinnost předat odůvodnění osobě, které správní akt zasahuje do jejich práv, svobod či zájmů. Rezoluce zdůrazňuje nejzásadnější smysl odůvodnění, a to ochranu subjektivních práv účastníků. Příručka základních principů správního práva $\mathrm{k}$ danému uvádí, že otázka rozsahu odůvodnění je ponechána správním orgánům, které určí rozsah odůvodnění podle okolností případu s tím, že budou mít stále na vědomí základní smysl odůvodnění, jimž je umožnit adresátům zhodnotit správní rozhodnutí samotné. ${ }^{5}$ Velký význam v rámci této problematiky má i Doporučení Výboru ministrů Rady Evropy (80) $2^{6}$, které se věnuje specifickým otázkám výkonu diskreční pravomoci a zdůrazňuje v tomto kontextu význam odůvodnění rozhodnutí. Neméně významným dokumentem je i Doporučení Výboru ministrů Rady Evropy (2007)7. Toto doporučení pak zdůrazňuje odůvodnění správního rozhodnutí nejen v jeho aspektu ochrany veřejných subjektivních práv účastníků rízení, ale řadí odůvodnění i mezi náležitosti výkonu dobré veřejné správy.7

Pro stanovení konkrétnějšího minimálního (a zejména závazného) standardu obsahu odůvodnění správního rozhodnutí má větší význam judikatura ESLP. Podle judikatury ESLP musí odůvodnění obsahovat zásadní, stěžejní důvody, na kterých je rozhodnutí postaveno, přičemž rozsah povinnosti uvést důvody musí odpovídat okolnostem případu. ${ }^{8}$ Je vhodné zmínit, že odůvodnění rozhodnutí nemusí obsahovat detailní odpověd’ na každý jednotlivý argument účastníků, avšak musí dosahovat minimálně takové kvality (obsahovat dostatečné množství argumentů), aby účastníkům nebyla znemožněna obrana v rámci řízení o odvolání. Uvedené postupem času ESLP upřesnil a dospěl ke konceptu tzv. úplnosti odůvodnění rozhodnutí. Z konceptu úplnosti nelze dovozovat,

4 Rezoluce Výboru ministrů Rady Evropy (77) 31. In: Council of Europe [cit. 5. 11. 2015]. Dostupné z: $<$ https://wcd.coe.int/com.instranet.InstraServlet?command=com.instranet.CmdBlobGet\&Instranet Image $=2009032 \&$ SecMode $=1 \&$ DocId $=752646 \&$ Usage $=2>$.

5 The administration and You. Principles of administrative law concerning the relations between administrative authorities and private persons A handbook [online]. Council of Europe [cit. 5. 11. 2015] s. 344-345. Dostupné z: < http://www.coe.int/t/dghl/standardsetting/cdcj/Handbook\%20on\%20Administration $\% 20$ and $\% 20 \mathrm{You} /$ Admin $\% 20$ and $\% 20$ youE.pdf $>$.

6 Doporučení Výboru ministrů Rady Evropy (80) 2. In: Council of Europe [cit. 5. 11. 2015]. Dostupné z: <https://wcd.coe.int/com.instranet.InstraServlet?command=com.instranet.CmdBlobGet\&Instranet Image $=2009056 \&$ SecMode $=1 \&$ DocId $=667512 \&$ Usage $=2>$.

7 Doporučení Výboru ministrů Rady Evropy (80) 2. In: Council of Europe [cit. 5. 11. 2015]. Dostupné z: <https://wcd.coe.int/com.instranet.InstraServlet?command=com.instranet.CmdBlobGet\&Instranet Image $=2009056 \&$ SecMode $=1 \&$ DocId $=667512 \& U$ sage $=2>$.

8 Rozsudek Evropského soudu pro lidská práva ze dne 25. 12. 2001, sp. zn. 49684/99 (prrípad Hirrvissaari proti Finsku). HUDOC [online]. Evropský soud pro lidská práva, C 2001 [cit. 5. 11. 2015]. Dostupné z: <http://hudoc.echr.coe.int/eng?i=001-59682\#\{,,itemid“:[,001-59682“]\}>.

9 Rozsudek Evropského soudu pro lidská práva ze dne 19. 4. 1994, sp. zn. 16034/90 (př́pad Van de Hurk proti Nizozemî). HUDOC [online]. Evropský soud pro lidská práva, C 1994 [cit. 5. 11. 2015]. Dostupné z: < http://hudoc.echr.coe.int/eng?i=001-57878\#\{,itemid“:[,,001-57878“]\}>. 
že by správní orgán musel detailně (výslovně) odpovědět na každý jednotlivý argument účastníka. Postačí, aby správní orgán detailně reagoval na podstatné argumenty vznesené účastníkem a jeho ostatní (pro projednávanou věc nedůležité) argumenty či další (spíše dílčí) sporné otázky byly vypořádány méně detailním způsobem.

Autor upozorňuje, že zásada řádného odůvodnění definovaná judikaturou ESLP obsahuje jeden dílčí problém. Podle autorova názoru nelze dopředu vytvořit přesnou definici zásadních argumentů a jak takové argumenty poznat. ${ }^{10}$ Je zřejmé, že ve většině př́ipadů nebude identifikace zásadních problémů př́liš složitá. V takové situaci správní orgán odpoví na hlavní otázku, a pokud touto odpovědí z povahy věci samé vypořádá i další, dílčí, méně podstatné argumenty, pak tyto zbývající argumenty výslovně vypořádat nemusí. Jelikož však mohou vznikat i situace, kdy správní orgán bude v nejistotě, která otázka je hlavní (a to zejména, je-li sporných otázek více), pak lze doporučit výslovně vypořádat veškeré argumenty účastníků, byt’ i zdánlivě marginální. Takový postup lze zvolit i v situaci, kdy chce správní orgán docílit vyšší přesvědčivosti rozhodnutí. Ostatně správní orgány by měly vždy mít na žreteli i otázku přesvědčivosti rozhodnutí, aby nedocházelo k napadení rozhodnutí jen pro jejich nepochopení adresátem. ${ }^{11}$ Řada účastníků necítí jako prríliš přivětivý přístup situaci, kdy správní orgán přednese toliko vlastní argumentaci, avšak argumentům účastníkům se výslovně nevěnuje. Takové odůvodnění rozhodnutî je po obsahové stránce jistě správné a zákonné. Navíc pokud účastníci záměrně volî obstrukční metody a napadají i zcela triviální věci bude zmíněný postup jediný možný, nebot' jinak může dojít až k zahlcení správního orgánu. Byt' to judikatura ESLP přímo nevyžaduje, může být v řadě situací pro správní orgán výhodnější, pokud výslovně reaguje na argumenty účastníků, čímž zároveň zvýší přesvědčivost rozhodnutí. Podle autora se uvedeným postupem podpoři komunikační funkce odůvodnění rozhodnutí, což může pomoci dojít ke smírnému vyřešení věci mezi účastníkem a správním orgánem, tedy že účastník rozhodnutí př́jme a nepodá opravný prostředek. Myšlenku lze doplnit s tím, že i samotná volba metody odůvodnění má zásadní důsledky pro výsledek rozhodnutí jako takového, tj. zda bude či nebude napadeno opravný prostředkem.

\section{3 Česká republika}

V České republice získává povinnost odůvodnit správní rozhodnutí na významu v souvislosti se změnami po roce 1989 a začíná plnit své garanční funkce ve vztahu k ochraně práv účastníků. Teorie i praxe považuje povinnost odůvodnit správní rozhodnutí za součást

10 Rozsudek Evropského soudu pro lidská práva ze dne 25. 12. 2001, sp. zn. 49684/99 (př́pad Hirrvissaari proti Finsku). HUDOC [online]. Evropský soud pro lidská práva, C 2001 [cit. 5. 11. 2015]. Dostupné z: <http:// hudoc.echr.coe.int/eng?i=001-59682\#\{,,itemid“:[„,001-59682“]\}>.

11 Přesvědčivost rozhodnutí řadí mezi aspekty dobré správy i Veřejný ochránce práv. In: Principy dobré spráyy [online]. Veřejný ochránce práv [cit. 5. 11. 2015]. Dostupné z: <http://www.ochrance.cz/ stiznosti-na-urady/pripady-a-stanoviska-ochrance/principy-dobre-spravy/>. 
práva na spravedlivý proces ${ }^{12}$. Autor se prriklání k názoru, že povinnost odůvodnit správní rozhodnutí lze považovat za právní zásadu. ${ }^{13}$ Podle současné právní úpravy ve správním rádu jsou správní orgány v rámci odůvodnění povinny uvést důvody rozhodnutí a zejména úvahy, kterými se rrídily při výkladu právních předpisů a hodnocení podkladů ř́zení s tím, že uvedou, jak se vypořádaly s námitkami (argumenty) účastníků. ${ }^{14}$ Zásada řádného odůvodnění v českém prostředí získala na významu zejména vlivem judikatury Ústavního a Nejvyššího správního soudu. Zmíněné soudy v rámci svého rozhodování vyložily aspekty zásady rádného odůvodnění, respektive rozsah povinnosti odůvodnit správní rozhodnutí. Prvotní judikatura správních soudů zdůraznila především existenci této povinnosti a její dílčí aspekty ${ }^{15}$, následně pak docházelo k její konkretizaci. ${ }^{16}$ Podle aktuální judikatury je povinností správních orgánů mimo uvedení zásadních právních a skutkových úvah rovněž vypořádat všechny, byt’ i marginální argumenty účastníků, zejména v řízení o žádostech. ${ }^{17} \mathrm{~V}$ této souvislosti lze rovněž hovořit o konceptu úplnosti odůvodnění, který je podle autora svými nároky na správní orgány velmi podobný požadavku úplnosti odůvodnění uvedeném v judikatuře ESLP. Koncept úplnosti odůvodnění uvedený v judikatuře NSS nemá znamenat, že musí být výslovně reagováno na každý konkrétní argument účastníka. Plně postačí, pokud správní orgán předestře vlastní úvahy, které z povahy věci vypořádají všechny argumenty účastníka. Podle názoru autora NSS nevyžaduje vyšší standard odůvodnění, než byl definován judikaturou ESLP.

Zákonná úprava v určitých situacích umožňuje vydat (jakožto výjimku z povinnosti odůvodnit) rozhodnutí bez odůvodnění, pokud správní orgán prvního stupně vyhoví všem účastníkům v plném rozsahu. ${ }^{18}$ Zákon tuto možnost předpokládá pouze pro situace, kdy právní úprava spojuje se splněním podmínek jediný možný následek. ${ }^{19}$ Pokud do-

12 MOLEK, Pavel. Právo na spravedlivý proces. 1. vyd. Praha: Wolters Kluwer Česká republika, 2012, s. 207. Z aktuální judikatury Ústavního soudu pak nález ze dne 23. 4. 2015, sp. zn. III. ÚS 197/15. In: ASPI [právní informační systém]. Wolters Kluwer ČR [cit. 5. 11. 2015].

13 Obdobně SKULOVÁ, S. In: SKULOVÁ, Soňa; KLIKOVÁ Alena a David HEJČ. Prostréedky ochrany subjektivních práv ve verejné správě: sborník prǐspèvkei z workshopu. 1. vyd. Brno: Masarykova univerzita, 2014, s. 54.

14 VEDRAL, Josef. Správní rád: komentár. 2. aktualiz. a rozš. vyd. Praha: Ivana Hexnerová - Bova Polygon, 2012, s. 612.

15 Rozsudek Vrchního soudu v Praze ze dne 26. 2. 1993, sp. zn. 6 A 48/92. In: ASPI [právní informační systém]. Wolters Kluwer ČR [cit. 5. 11. 2015].

16 Rozsudek Nejvyššího správního soudu ze dne 10. 4. 2008, č. j. 7 Afs 212/2006-88. In: ASPI [právní informační systém]. Wolters Kluwer ČR [cit. 5. 11. 2015].

17 Usnesení rozšířeného senátu Nejvyššího správního soudu ze dne 8. 12. 2009, č. j. 8 Afs 73/2007 - 111. In: ASPI [právní informační systém]. Wolters Kluwer ČR [cit. 5. 11. 2015].

18 Zákon č. 500/2004 Sb., správní řád, ve znění pozdějších předpisů. In: ASPI [právní informační systém]. Wolters Kluwer ČR [cit. 5. 11. 2015].

19 VEDRAL, Josef. Správni rád: komentár. 2. aktualiz. a rozš. vyd. Praha: Ivana Hexnerová - Bova Polygon, 2012, s. 614. Složkové předpisy pak umožňují správním orgánům, aby upustily od tvorby odůvodnění, např. pokud převáží zájem na ochraně informací apod. Viz např. \122 odst. 3 zákona č. 412/2005 Sb., o ochraně utajovaných informací a o bezpečnostní způsobilosti, ve znění pozdějších předpisů. In: $A S P I$ [právní informační systém]. Wolters Kluwer ČR [cit. 5. 11. 2015]. 
jde k naplnění podmínky, že správní orgán vyhoví všem účastníkům, pak bude právní úprava z hlediska ochrany práv účastníků dostačující. Primárně je odůvodnění prostředkem ochrany práv konkrétních adresátů veřejné správy, a ty $\mathrm{v}$ tomto př́padě nebyly nijak narušeny. Pokud správní orgán rozhodnutí neodůvodní, přestože tak měl učinit (např. při využití diskreční pravomoci nebo při výkladu neurčitých pojmů), pak dojde nejen k porušení zákona, ale i práva na spravedlivý proces. V takové situaci nezbývá adresátovi nic jiného, než rozhodnutí napadnout opravným prostředkem. Nadřízený správní orgán pak musí rozhodnutí zrušit pro nepřezkoumatelnost, nebot' bez odůvodnění není schopen účinně přezkoumat úvahu orgánu prvního stupně, ani zda byly skutečně naplněny podmínky \68 odst. 4 správního řádu. Správní orgány by tedy měly vždy důsledně zjišt'ovat, zda byly naplněny zákonné podmínky pro vydání rozhodnutí bez odůvodnění, zejména je-li účastníků více.

\section{Německo}

Německý správní rád v \39 vyžaduje, aby správní akty (mezi něž řadí i rozhodnutí) obsahovaly odůvodnění. Teorie $\mathrm{v}$ této souvislosti hovoří o povinnosti odůvodnění, přičemž teorie ji označuje za zásadu a projev dobré správy. ${ }^{20}$ Obsahem „Begründungspflicht je povinnost správního orgánu uvést $\mathrm{v}$ rámci odůvodnění právní a skutkové předpoklady a úvahy, které správní orgán k rozhodnutí vedly. Teorie považuje odůvodnění za jeden ze základních předpokladů efektivní právní ochrany a zdůrazňuje, že v odůvodnění rozhodnutí musí být uvedeny opravdu roz̧hodujicí důvody. Podle názoru autora správní orgány nemusí detailně odpovídat na veškeré argumenty vznesené účastníkem či veškeré právní otázky, nýbrž postačí uvést podstatné důvody vedoucí k přijatému rozhodnutí, pokud z povahy věci vypořádají i zbývající dílčí argumenty. Doktrína za tzv. rozhodující důvody označuje ty, které jsou pro daný typ řízení obvyklé a typické. ${ }^{21}$ Rovněž je nezbytné, aby se odůvodnění vztahovalo k danému konkrétnímu př́padu a nebylo pouhým obecným strojovým odůvodněním. Lze tedy konstatovat, že i v německém prostředí se ujal tzv. koncept úplnosti rozhodnutí, který se svým obsahem neliší od českého. Podle doktríny z principu právního státu vyplývá, že adresát správního rozhodnutí má právo na to, aby mu byly oznámeny důvody, proč bylo zasaženo do jeho práv, nebot’ bez uvedení důvodů nemůže efektivně bránit svá práva. ${ }^{22} \mathrm{~V}$ rámci odůvodnění rozhodnutí je potřebné uvést, proč bylo např́íklad zasaženo do určitého základního práva, respektive proč správní orgán nezvolil jiné řešení. Tento aspekt je velmi zajímavý. Teorie totiž uvádí, že správní orgán má vážit pro a proti daného rozhodnutí zejména s ohledem na veřejný zájem a zájmy adresátů rozhodnutí, tj. provést test proporcionality, což je úkol velmi

20 Verwaltungsverfahrensgesetz: 13., vollständig überarbeitete Aufl. München: C. H. Beck, 2012, s. 791.

21 Verwaltungsverfahrensgesetz. 13., vollständig überarbeitete Aufl. München: C. H. Beck, 2012, xxx, s. 799.

22 STELKENS, Paul; BONK Heinz Joachim a Michael SACHS. Verwaltungsverfahrensgesetz: Kommentar. 8. Aufl. München: C. H. Beck, 2014, s. 1311. 
náročný. Pokud odůvodnění obsahuje precizně vyargumentovaný test proporcionality je takové rozhodnutí přesvědčivé a argumentačně silné. ${ }^{23}$

Německý správní rád připouští v zájmu efektivního výkonu veřejné správy výjimky z povinnosti odůvodnit správní rozhodnutí, které však musí být uplatňovány restriktivně a ústavněkonformním způsobem. ${ }^{24}$ Prvním př́padem, kdy zákon umožňuje, aby rozhodnutí bylo vydáno bez odůvodnění, je vydání rozhodnutí, kterým se plně vyhovuje žádosti účastníka, aniž by tímto rozhodnutí bylo zasaženo do práv jiné osoby. Tato právní úprava je svým obsahem velmi podobná té české, avšak výslovně zdůrazňuje podmínku, aby nebylo zasaženo do práv osob jiných, což česká právní úprava sice výslovně nečiní, byt' to lze z jejího obsahu rovněž dovodit.

Další výjimku z povinnosti odůvodnit správní rozhodnutí tvoří specifický koncept tzv. znalosti a rozpoznatelnosti věcné a právní stránky věci. Tento koncept předpokládá, že správní orgán může vydat rozhodnutí bez odůvodnění v situaci, kdy je v průběhu řízení účastník seznámen s právním názorem a skutkovým hodnocením správního orgánu. Toho může být docíleno například tím, že správní orgán zašle účastníkovi ,informační leták“, kde je „vše“ uvedeno. Vychází se z premisy, že ze zmíněného letáku jednoznačně a zcela bez dalšího vyplývá hodnocení věci správním orgánem. Autor uvádí, že německý zákonodárce zde zvolil cestu určitého „předodůvodnění“. Sdělení důvodů musí být vždy písemné, nebot' teorie uvádí, že nepostačí pouhé ústní sdělení důvodů, byt' by byly sděleny v průběhu ústního jednání. Pokud se totiž spoléhá na připravené materiály, respektive $\mathrm{v}$ průběhu řízení předává písemné informace, které by měly odpovídat okolnostem řízení, pak svým způsobem účastníkovi předává odůvodnění již v průběhu řízení samotného. Obecná právní úprava pak nedává jednoznačnou odpověd’ na otázku, jak se př́padně bránit proti takovémuto správnímu rozhodnutí. Pokud totiž rozhodnutí nemá odůvodnění, nelze než namítat jeho nepřezkoumatelnost. Autor se však domnívá, že pokud účastník již v průběhu řízení projevil nesouhlas s „předodůvodněním“, musí být vydáno rozhodnutí s odůvodněním, se kterým pak může účastník v rámci řízení o opravných prostředcích věcně polemizovat.

Německý správní rád umožňuje vydávat správní rozhodnutí bez odůvodnění i v případě, kdy správní orgán vydává rozhodnutí typově shodná či vytvořená pomocí automatických zařízení. V praxi se má jednat o rozhodnutí, která nejsou „případem jednotlivých osudư“, nýbrž se jedná o typově shodné situace. Toto ustanovení bylo součástí správního řádu od okamžiku jeho přijetí v roce 1976 a postupem času v důsledku rozvoje technických prostředků pozbylo významu. Jeho základním smyslem mělo být ulehčit veřejné

23 Autor se domnívá, že i české správní orgány mohou využít testu proporcionality zejména při střetu ústavně chráněných práv jedince s veřejným zájem např. při vyvlastňování pozemků pro liniové stavby.

24 STELKENS, Paul; BONK, Heinz Joachim a Michael SACHS. Verwaltungsverfahrensgesetz: Kommentar. 8. Aufl. München: C. H. Beck, 2014, s. 1332. 
správě přípravu rozhodnutí, což dnes vzhledem $\mathrm{k}$ dostupnosti počítačové techniky již neobstojí. Byt' tedy zákon tuto možnost uvádí, praxe tohoto ustanovení neužívá. ${ }^{25}$

\section{Rakousko}

Rakouský obecný správní řád ukládá správním orgánům povinnost rozhodnutí odůvodnit v $\int 58$ odst. 2. Tato povinnost vyplývá podle teorie z principu právního státu ${ }^{26}$ a je potvrzena i judikaturou spolkového soudního správního dvora. ${ }^{27}$ Podle $\int 60$ obecného správního řádu musí být v odůvodnění uvedeny výsledky dokazování, hodnocení důkazů a s tím spojené vyhodnocení právních otázek, které musí být uvedené jasně a přehledně. ${ }^{28}$ Účastník řízení má být informován dostatečným a ,využitelným“ způsobem. Postačí výslovně uvést zásadní, nosné a rozhodující důvody. ${ }^{29} \mathrm{Z}$ judikatury pak vyplývá, že není nutné odpovídat detailně na každý argument, nicméně je potřebné, aby každý argument účastníka byl vypořádán alespoň qákladním způsobem, např́iklad tím, že správní orgán uvede vlastní úvahy, které samy o sobě z povahy věci vyloučí argumenty účastníků. V této souvislosti lze konstatovat, že i v Rakousku platí tzv. koncept úplnosti odůvodnění. Teorie zdůrazňuje, že odůvodnění slouží zejména k ochraně oprávněných zájmů (práv) účastníků ř́zenín ${ }^{30}$, což potvrzuje i judikatura ${ }^{31}$. Podle rakouské doktríny má odůvodnění zejména bránit libovưli státu vưči účastníkovi řízení. Právní úprava připouští z povinnosti odůvodnění výjimky, a to v situaci, kdy správní orgán plně vyhoví žádosti účastníka. Záměrem této úpravy je zvýšení efektivity veřejné správy za situace, kdy jsou práva účastníků dostatečně chráněna. Jelikož právní úprava je, alespoň z hlediska textu zákona, stejná jako v České republika, přináší proto i obdobná rizika či nedokonalosti. Právní úprava neuvádí výslovně, jak naložit s rozhodnutím bez odůvodnění, pokud bylo vydáno, aniž byly pro daný postup splněny zákonné podmínky. Lze se domnívat,

25 Verwaltungsverfahrensgesetz. 13., vollständig überarbeitete Aufl. München: C. H. Beck, 2012, xxx, s. 799.

26 HENGSTSCHLÄGER, Johannes a David LEEB. Kommentar zum Allgemeinen Verwaltungsverfahrensgesetz: Wien: Manzsche Verlags- und Universitätsbuchhandlung, 2005, s. 685.

27 Rozsudek Spolkového soudního správního dvora ze dne 8. 7. 1991, sp. zn. 91/19/0096. Bundeskanzleramt Rechtsinformationssystem [online]. Bundeskanzleramt [cit. 5. 11. 2015]. Dostupné z: <https://www. ris.bka.gv.at/Dokumente/Vwgh/JWR_1991190096_19910708X01/JWR_1991190096_19910708X01. html>.

28 HENGSTSCHLÄGER, Johannes a David LEEB. Kommentar zum Allgemeinen Verwaltungsverfahrensgesetz: Wien: Manzsche Verlags- und Universitätsbuchhandlung, 2005, s. 743.

29 KOLONOVITS, Dieter; MUZAK; Gerhard a Karl STÖGER. Grundriss des österreichischen Verwaltungsverfahrensrechts: einschließlich der Verfahren vor den Verwaltungsgerichten und vor dem VwGH. 10. Aufl. Wien: Manzsche Verlags- und Universitätsbuchhandlung, 2014, s. 254.

30 HENGSTSCHLÄGER, Johannes a David LEEB. Kommentar zum Allgemeinen Verwaltungsverfahrensgesetz: Wien: Manzsche Verlags- und Universitätsbuchhandlung, 2005, s. 745.

31 Rozsudek Spolkového soudního správního dvora ze dne 29. 5. 1990, sp. zn. 89/04/0224. Bundeskanzleramt Rechtsinformationssystem [online]. Bundeskanzleramt [cit. 5. 11. 2015]. Dostupné z: <https://www.ris.bka. gv.at/Dokumente/Vwgh/JWR_1989040224_19900529X02/JWR_1989040224_19900529X02.html>. 
že osoba, která nesouhlasí s rozhodnutím, bude mít možnost podat žalobu proti danému rozhodnutí s tím, že namítne nepřezkoumatelnost rozhodnutí. ${ }^{32}$

\section{Polsko}

Podle čl. 107 odst. 1 polského správního řádu je odůvodnění nedílnou součástí rozhodnutí. Podle odstavce 3 zmíněného ustanovení má správní orgán v odůvodnění rozhodnutí uvést skutkové důvody, o které rozhodnutí opřel, proč neprijal určité důkazy a k jakým právním závěrům a z jakých důvodů dospěl. Judikatura zdůrazňuje, že správní orgány mají uvést konkrétní důvody, které vedly k rozhodnutí, a které považovaly za rozhodující a důležité. ${ }^{33}$ Judikatura dále klade velký důraz na to, aby účastníkům byly sděleny skutečné (pravdivé) důvody rozhodnutí v odpovídajícím, přiměřeném rozsahu vzhledem k okolnostem případu. Bez uvedení důvodů vedoucích k přijetí rozhodnutí účastnici nemají možnost odpovídajícím způsobem bránit svá veřejná subjektivní práva, at' už před odvolacím správním orgánem či správním soudem. Pokud správní orgán neuvede zásadni důvody vedoucí k rozhodnutí, pak tím podle polského Nejvyššího správního soudu poruší základní zásady správního rrízení. ${ }^{34}$ Podle autora i v Polsku platí tzv. koncept úplnosti odůvodnění. Jako řádné pak lze podle doktríny označit takové odůvodnění, které je logické, vnitřně nerozporné, obsahuje pravdivé argumenty a zároveň je stručné a úplné, ${ }^{35}$ a svým rozsahem odpovídá okolnostem př́padu. ${ }^{36}$ I polské správní právo umožňuje vydat rozhodnutí zcela bez odůvodnění, a to v situaci, kdy správní orgán plně vyhoví žádosti účastníka. ${ }^{37}$ Polská právní úprava je velmi blízká té české, nicméně s tím rozdílem, že rozhodnutí bez odůvodnění lze vydat jen v případě, kdy má řízení jediného účastníka. Tímto zpřesněním má být zamezeno vydání rozhodnutí bez odůvodnění pro případ, že řízení má více účastníků s protichůdnými zájmy. ${ }^{38}$ Správní orgán může vydat rozhodnutí bez odůvodnění i v situaci, kdy převáží zájem státu na ochraně tajných informací. Při takovém postupu nicméně mají být uvedeny důvody, které správní orgán vedly $\mathrm{k}$ neuvedení informace, respektive má být vyloženo, proč převážil zájem státu

32 Od 1. 1. 2014 bylo odvolací řízení zásadně omezeno a řádným opravným prostředkem je žaloba, respektive stížnost proti správnímu rozhodnutí.

33 PRZYBYSZ, Piotr. Kodeks postępowania administracyjnego: komentarz. 10. wyd. Warszawa: LexisNexis, 2013, s. 314.

34 I polská praxe tedy řadí povinnost odůvodnit správní rozhodnutí mezi právní zásady.

35 FEDERCZYK, Wojciech, Michał KLIMASZEWSKI a Bartosz MAJCHRZAK. Postepowanie administracyjne. 3. wyd. Warszawa: Wydawnictwo C. H. Beck, 2013, xxv, s. 166.

36 ADAMIAK, Barbara a Janusz BORKOWSKI. Kodeks postepowania administracyjnego: komentar\%. 13. wyd. Warszawa: Wydawnictwo C. H. Beck, 2014, xx, s. 464.

37 MUDRECKI, Artur a Lidia KLAT-WERTELECKA. Kodeks Kodeks postępowania administracyjnego komentáry dla praketyków z suplementem elektronicそnym. 1. wyd. Gdańsk: Wydawnictwo ODDK, 2012, s. 455.

38 MUDRECKI, Artur a Lidia KLAT-WERTELECKA. Kodeks Kodeks postepowania administracyjnego komentáry dla prak.tyków z suplementem elektronicznym. 1. wyd. Gdańsk: Wydawnictwo ODDK, 2012, s. 455. 
na ochraně informace. Proto nelze hovořit o úplné absenci odůvodnění, nebot' rozhodnutí má obsahovat alespoň jakési „náhradni“" odůvodnění.

\section{Závěr}

Na závěr autor uvádí, že zásada řádného odůvodnění prošla postupným vývojem a dnes je odůvodnění chápáno jako důležitá součást systému ochrany veřejných subjektivních práv. Autor uvádí, že povinnost odůvodnit rozhodnutí nabyla velkého významu i díky Radě Evropy, a zejména judikatuře ESLP, která povinnost odůvodnit správní rozhodnutí v evropském správním prostoru potvrdila, a zároveň pomohla definovat určitý minimální standard povinnosti odůvodnění. V rozporu se zásadou řádného odůvodnění nejsou výše uvedené výjimky z povinnosti odůvodnit správní rozhodnutí. Je-li dodržena zákonná úprava, pak jsou dostatečně chráněna práva účastníků tím, že se jim v plném rozsahu vyhoví. Akcent ochrany práv účastníků prostřednictvím odůvodnění ukazuje i vývoj v Německu, kde dříve preferovaný přístup zdůrazňující zejména rychlost a efektivitu řízení byl postupně opuštěn a rozsah výjimek z povinnosti odůvodnit správní rozhodnutí se zmenšil. Výjimky z povinnosti odůvodnit podle autora spíše naráží na požadavky transparentního výkonu veřejné správy a skryté (neznámé) důvody rozhodnutí mohou snadno vyvolávat kontroverze. Byt' v některých př́padech může převážit zájem efektivity a rychlosti výkonu veřejné správy nad snahou o co nejvyšší transparentnost, přesto by do budoucna měl zájem zákonodárce směrovat k většímu využití potenciálu odůvodnění $\mathrm{k}$ transparentnímu výkonu veřejné správy. $\mathrm{V}$ rámci úvah de lege ferenda je možné uvažovat o zavedení povinnosti vypořádat otázky veřejného zájmu přímo v \68 odst. 3 správního řádu. ${ }^{39}$ I přes výše uvedené je však autor názoru, že veřejná správa a soudy si již uvědomují význam odůvodnění a jeho role jakožto prostředku ochrany veřejných subjektivních práv stoupá. Jak vyplývá z výše uvedeného, povinnost odůvodnit správní rozhodnutí se objevuje ve všech výše uvedených zemích a rozsah této povinnosti se při základním pohledu do zkoumaných států př́liš neliší. Všechny čtyři státy ve svých právních řádech i judikatuře respektují požadavky ESLP, respektive Rady Evropy. Rovněž i nároky plynoucí z právní úpravy jsou pak velmi podobné. Pro uvedené státy platí, že správní orgány jsou v odůvodnění správních rozhodnutí povinny uvést zásadní a podstatné (pravdivé) argumenty, právní a skutkové důvody vedoucí k rozhodnutí s tím, že je potřeba uvést vždy vypořádání argumentů účastníků řízení. Ve všech zkoumaných státech se uplatňuje tzv. koncept úplnosti odůvodnění. Je proto možné článek uzavřít $\mathrm{s}$ tím, že zásada řádného odůvodnění může být považována za společně sdílenou zásadu evropských demokratických států.

39 Byt' správní řád na více místech (nap̌r. v \ 2 odst. 4) hovoří o nutnosti postupovat v souladu s veřejným zájmem, autor je názoru, že výslovná právní úprava $\mathrm{v}$ rámci odůvodnění vypořádat otázky veřejného zájmu může být vhodnější a pro postup správních orgánů návodnější. 